\title{
Non-Hodgkin's Lymphoma in a Child Presenting as Ileo-Colic Intussusception- A Case Report
}

\author{
Dr. Sarita Nibhoria ${ }^{1}$, Dr. Manmeet Kaur ${ }^{2 *}$, Dr. Prerna Chhabra ${ }^{3}$
}

${ }^{1}$ Professor \& Head, Department of Pathology, Guru Gobind Singh Medical College \& Hospital, Sadiq Rd, Faridkot, Punjab, India

${ }^{2}$ Associate Professor, Department of Pathology, Guru Gobind Singh Medical College \& Hospital, Sadiq Rd, Faridkot, Punjab, India

${ }^{3}$ Senior Resident, Department of Pathology, Guru Gobind Singh Medical College \& Hospital, Sadiq Rd, Faridkot, Punjab, India

DOI: $10.36347 /$ sjmcr.2020.v08i01.023

| Received: 16.01.2020 | Accepted: 23.01.2020 | Published: 26.01 .2020

*Corresponding author: Dr. Manmeet Kaur

Abstract

Primary tumors of the gastrointestinal tract are rare in children and represent less than 5\% of all pediatric neoplasm. Non-Hodgkin's lymphoma (NHL) remains the most common malignancy of the GI tract in children. Yet, the overall incidence is very low. We report a case of ileocaecal NHL in a child presenting with intussusception.

Keywords: Non-Hodgkin's lymphoma, Pediatric lymphoma, Intussusception, Ileocaecal lymphoma, B-cell lymphoma.

Copyright @ 2020: This is an open-access article distributed under the terms of the Creative Commons Attribution license which permits unrestricted use, distribution, and reproduction in any medium for non-commercial use (NonCommercial, or CC-BY-NC) provided the original author and source are credited.

\section{INTRODUCTION}

Malignant lymphomas are the third most common type of childhood cancer [1]. Children typically present with diffuse extranodal disease in contrast to adults among whom primary nodal disease is common. Primary non-Hodgkin's lymphoma (NHL) of the gastrointestinal tract is the most common extranodal lymphoma in pediatric age group. Yet, the overall incidence is very low [2]. The lesser frequency of the disease and its variable clinical presentation cause a hindrance to its early detection albeit the existence of a possible cure.

Intussception often occurs around 1 year of age, in infants aged 9-24 months, it is usually primary i.e. they do not have an identifiable specific lead point. A specific lead point is more commonly found in children older than 3 years [3]. Though uncommon, primary Non-Hodgkin's lymphoma (NHL) is found to be the lead point in intussusception.

We hereby report a case of primary caecal lymphoma in a 5 year old child presented as acute abdomen due to intussusception.

\section{CASE Report}

A 4.5 years old male child presented with complaint of abdominal pain since two days along with on and off passage of loose stools. There was no history of vomiting. Local examination revealed a palpable non-tender lump in the lumbar region. There was no generalized lymphadenopathy or hepatosplenomegaly.

Ultrasonography of the abdomen revealed a whirlpool like bowel mass at epigastric and hypochondrium suggestive of intussusception. Resection of the involved segment of bowel with ileocolic anastomosis was done and the resected bowel specimen was sent for histopathological examination.

We received a resected segment of intestine measuring $4.5 \times 3 \times 2.5 \mathrm{~cm}$ along with attached appendix measuring $6 \mathrm{~cm}$ in length. Cut section of intestine shows polypoidal growth measuring $3 \times 1.8 \times 1.4 \mathrm{~cm}$. Microscopic examination showed features of lymphoproliferative disorder possibly Non-Hodgkin's Lymphoma. Seven lymph nodes were identified, all which showed reactive lymphoid hyperplasia microscopically. Immunohistochemistry for CD 20 was done and result was immunoreactive with a score of 4+ in neoplastic cells, confirming its B-cell origin. 


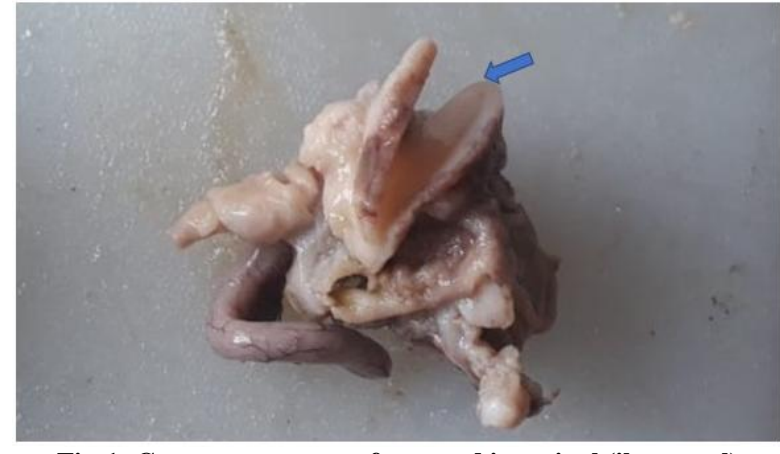

Fig-1: Gross appearance of resected intestinal (ileocaecal) segment showing polypoidal growth (arrow)

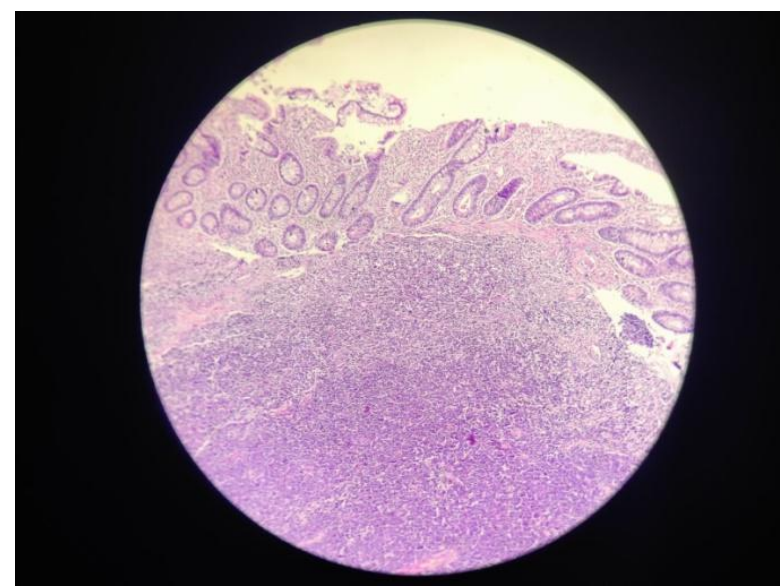

Fig-2: Photomicrograph showing presence of tumour (atypical lymphoid cells) beneath the mucosal epithelium. (H\& E; 100x)

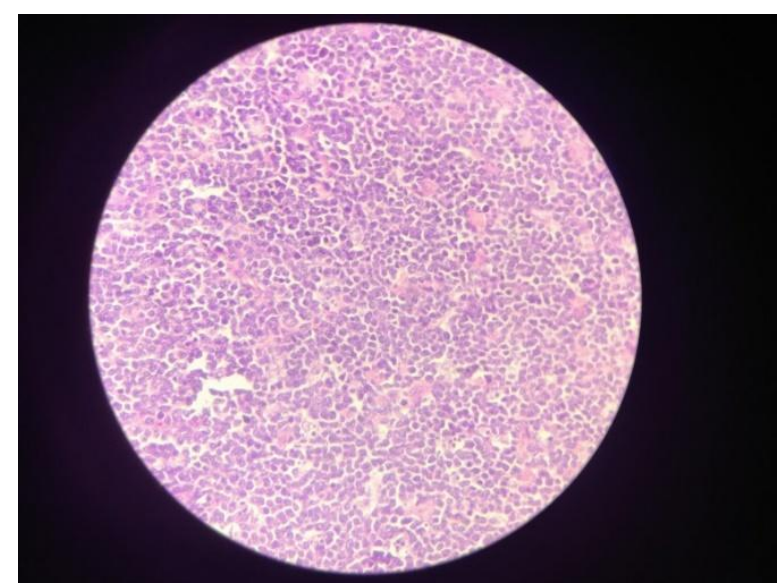

Fig-3: Photomicrograph showing sheet of atypical lymphoid cells (H\&E;400X)

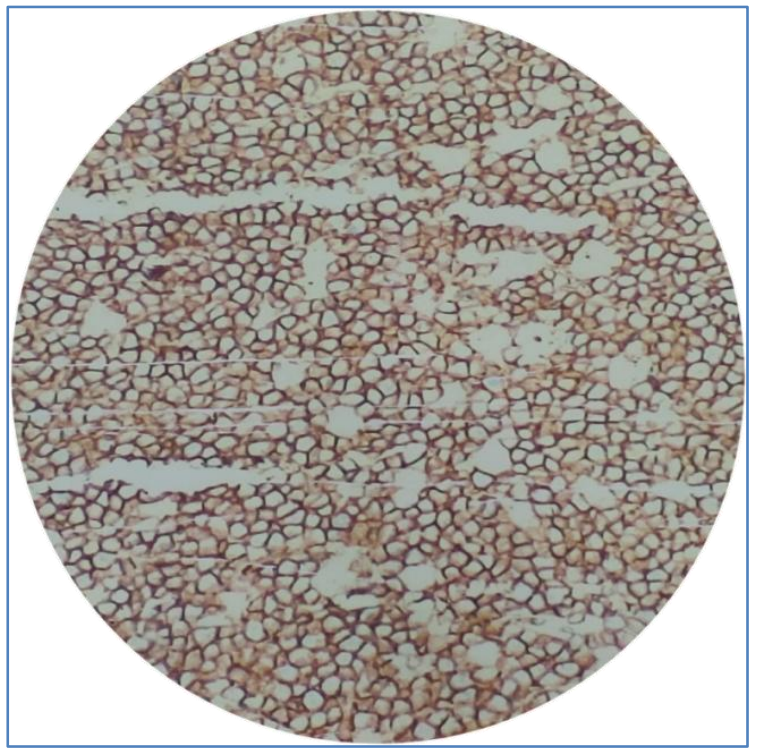

Fig-4: Photomicrograph showing tumour cells positive for CD 20 on Immunohistochemistry

\section{DiscuSSION}

Primary lymphoma of the small bowel is rare, accounting for less than $2 \%$ of the gastrointestinal malignancies and $10-20 \%$ of small bowel malignancies [4]. The peak age for NHL of GI tract in children is 515 years [5]. The male to female ratio of childhood GI NHL is reported to be from 7:1 to $1.8-2.5: 1[6,7]$. Study done by Bandyopadhyay et al. [2] reported six cases of pediatric GI lymphoma over a period of three years. The age at presentation ranged from 1 to 8 years. All of these patients were boys except one girl child who presented at a very early age (1 year).

The commonest presenting symptom is reported to be abdominal pain (81.4\%), followed by abdominal swelling, vomiting, constipation, diarrhea, and intestinal obstruction [6]. Nagaraj $\mathrm{H}$ et al. [8] reported diffuse large B-cell lymphoma of the intestine presenting as intussusception in a 5 year old child.

Shakya et al. [9] reported two cases of intussusception due to non-hodgkin's lymphoma in 3 year and 2 year old children respectively. Both tumours were positive for CD 20 i.e. of B cell origin.

Bandyopadhyay et al. [2] reported four out of six cases of pediatric lymphoma as Diffuse Large B cell lymphoma. The rest two cases were reported as Burkitt Lymphoma and Burkitt like lymphoma respectively. Chandraprakash A et al. [10] reported a case of diffuse large B-cell in ascending colon in a child with nonobstruction.

The ideal treatment approach in GI lymphoma remains controversial. Radical tumor resection followed by chemotherapy in early disease, and limited or no resection followed by polychemotherapy in advanced disease may be the justified approach. However, recent 
studies have proposed the use of chemotherapy alone as an effective treatment option in primary GI lymphoma in all stages [11].

\section{Conclusion}

Intussusception is more common in infants aged 6 to 24 months and its incidence decreases in children. But whenever a child above this age group presents with acute abdomen due to intussusception high index of suspicion should be there for the presence of primary lymphoma of the intestine.

\section{REFERENCES}

1. Sandlund JT, Downing JR, Crist WM. NonHodgkin's lymphoma in childhood. N Engl J Med. 1996; 334:1238-48.

2. Bandyopadhyay R, Sinha SK, Chatterjee U, Nag D, Mukhopadhyay S, Chowdhury SR, Biswas PK. Primary pediatric gastrointestinal lymphoma. Indian journal of medical and paediatric oncology: official journal of Indian Society of Medical \& Paediatric Oncology. 2011 Apr;32(2):92.

3. Aisenberg AC. Coherent view of non-Hodgkin's lymphoma. Journal of clinical oncology. 1995 Oct;13(10):2656-75.

4. Amer H, Zureikat, Matthew T, Heller, Herbert J Zeh. Cancer of the small intestine. DeVita. Cancer: Principle and Practice of Oncology 2011, 9th edition, 1055-1056.
5. Bethel CA, Bhattacharyya N, Hutchinson C, Ruymann F, Cooney DR. Alimentary tract malignancies in children. J Pediatr Surg. 1997; 32:1004-8

6. Ladd AP, Grosfeld JL. Gastrointestinal tumors in children and adolescents. Semin Pediatr Surg. 2006; 15:37-47.

7. Morsi A, Abd El-Ghani Ael-G, El-Shafiey M, Fawzy M, Ismail H, Monir M. Clinico-pathological features and outcome of management of pediatric gastrointestinal lymphoma. J Egypt Natl Canc Inst. 2005; 17:251-9.

8. HN, Raikar RN, Hebbar AK, Iyanna H, Kumar SBV. Non-Hodgkin's lymphoma of the intestine in a child presenting as intussusception- A case report and review of literature. Int J Res Health Sci. 2014 Jan31;2(1):347-9.

9. Shakya VC, Agrawal CS, Koirala R, Khaniya S, Rajbanshi S, Pandey SR, Adhikary S. Intussusception due to non-Hodgkin's lymphoma; different experiences in two children: two case reports. Cases journal. 2009 Dec 1;2(1):6304.

10. Ahirwar Chandraprakash. Primary Non-Hodgkin's Lymphoma of Ascending Colon in a Child with Non-Obstruction: a Case Report. Sch. J. App. Med. Sci. 2013; 1(4):273-275.

11. Raina V, Sharma A, Vora A, Shukla NK, Deo SV, Dawar R. Primary gastrointestinal non-Hodgkin lymphoma chemotherapy alone an effective treatment modality: Experience from a single center in India. Indian J Cancer 2006; 43:30-5. 